\title{
Immunodetection of EGF-receptor, c-erbB oncogenes and HSV-1 antigene in oral mucosal swab preparation from kretek (clove cigarette) smokers
}

\author{
Silvi Kintawati \\ Department of Oral Biology Faculty of Dentistry Universitas Padjadjaran
}

\section{ABSTRACT}

Smoking is the biggest factor for oral cavity malignancy. An oral cavity mucous swab was performed to 30 smokers (mild, moderate and severe) and 10 non smokers which was followed by immunocytochemistry smear using antibody for EGF-R, c-erbB, and HSV-1 antigenes to reveal the effect of smoking on the occurence of oral cavity malignancy. The results from this experiment are analyzed statistically using one-way Anava. It is discovered that based on the assessment of the expression level towards EGF-R, and $c$-erbB oncogene there is a very significant difference between the smoker group and non smoker group $(p<0.01)$. Meanwhile the results from the assessment towards HSV-1 oncogene do not show significant differences between the smoker group (mild, moderate and severe) and the non smoker group $(p>0.05)$. The results of this study shows that the more a person smokes, the higher possibility of oral cavity malignancy and that the antibody for EGF-R and c-erbB can be used as a marker for early detection of oral cavity malignancy caused by smoking.

Key words: Smoker, EGF-receptor, c-erbB, HSV-1, oncogene, immunocytochemistry

\section{INTRODUCTION}

Malignant tumors may be found in all parts of the human body including the oral cavity. Reports from various pathology center in Indonesia shows that around $3.2 \%$ of the malignant tumors are oral cavity malignant tumors. ${ }^{1}$

Oral cavity malignant tumors, just as other body part malignant tumors, are triggered by intrinsic or extrinsic risk factors. Epidemiologically, it has been shown that smoking is the biggest risk factor for oral cavity malignant tumor. ${ }^{2,3}$ The hot smoke that is inhaled continuously into the mouth is a physical thermal stimulant that brings bad effects on the oral tissue. On the other hand, the cigarette burned contains around 4,000 chemicals including some carcinogenic chemicals such as tar, nicotine and nitrosamine. It has been stated frequently that nitrosamine can trigger malignancy in human. ${ }^{4}$

Another factor that plays the role for oral cavity malignancy is virus. ${ }^{5}$ Herpes simplex virus in certain environment can be oncogenic and causes cell transformation. ${ }^{6}$ Several reports show that herpes simplex virus with nitrosamine found in tobacco can cause oncogene transformation. ${ }^{7}$ In severe tumor cells, it will be shown that EGF. receptors are found on the cell membrane surface 
and are considered as a product from the c-erbB oncogene. The EGF-receptor may be used as an important marker in making an early diagnosis of oral cavity malignant tumor. ${ }^{8}$ It has also been reported that antibody towards HSV-1 increases in oral cavity malignant tumor patients $\mathrm{s}^{9,10}$ and that oral cavity malignant tumor cells contain HSV-1 antigen on its cell membrane surface. ${ }^{11}$

Until now, routine examinations such as histopathological examination using hematoxylin eosin dye and cytological examination using Papanicolaou dye are frequently used to make the diagnosis. However, due to the accuracy in identifying various tumor/antigen markers, the use of immunohistochemistry/immunocytochemistry methods have been introduced in the pathology field during the last two decades. These methods can be used to manage various problems in diagnosing undiagnosed neoplasma using the routine examinations above.

Based on that reason, this study is performed to discover whether there is an increased expression of EGF-receptor and c-erbB oral cavity mucous cell swab retrieved from kretek smoker's oral cavity and there is an increased expressions of HSV-1.

By considering the fact that smoking is one of the biggest risk factors for oral cavity malignant tumor development ${ }^{2,3}$, there is a big possibility that an increased expression of EGF-receptor oncogenes, c-erbB and HSV-1 will be found in the mucous cell from oral swab in kretek smoker's oral cavity in line with the amount of cigarette consumption.

\section{MATERIALS AND METHODS}

This study is a laboratory study with "ex post facto" design. Thirty staff of Faculty of Dentistry, Universitas Padjadjaran, who are smokers were recruited as subjects for this study. The inclusion criteria include male, 40 years old or above who has been smoking from 5 years or more, and who is clinically proven as not having oral cavity abnormality. These smokers were grouped into mild smokers (less than 10 cigarettes a day), moderate smokers (between 11-20 cigarettes a day) and severe smokers (more than 20 cigarettes a day). As a comparison, 10 non smoker staff was also included in the study.
Oral swab was performed to these smokers and non smokers using wood spatula. The swab was smeared onto the object glass and was air-dried for 1 hour. The preparation was then fixated using ethyl alcohol for 1 hour followed by immunocytochemistry smear using Dako LSAB (Labelled Streptavidin Biotin/LSAB method) Kit Peroxidase.

\section{Antibody}

Antibodies used in this study were antibodies for EGF-receptor, c-erbB and HSV-1 antigene. The monoclonal antibody for EGF-R was purchased from Dako M866, Mo a Hu; klon EGFR-1; was diluted with a ratio of $1: 10$. Monoklonal antibody for c-erbB, was purchased from Dako A-0485, Mo a Hu diluted with a ratio of 1:50. Antibody for HSV-1 antigene, was purchased from Dako N1562 without diskated. LSAB kit peroxidase was purchased from Dako KO-681.

\section{Imunocytochemistry}

After the preparations were dried in open air and fixated using ethyl alcohol for one hour, they were incubated using $2 \% \mathrm{H}_{2} \mathrm{O}_{2}$ in methanol for 20 minutes. Next, the preparations were washed using $90 \%$ alcohol for 5 minutes, $80 \%$ alcohol for 5 minutes and $70 \%$ alcohol for 5 minutes and then treated by Tri Buffer Saline (TBS) for $3 \times 5$ minutes cycle. The preparations were then incubated using blocking reagent for 5 minutes, and then incubated using each antibody primer (EGF-receptor, c-erbB and HSV-1) for 30 minutes, washed by TBS for $3 \times 5$ minutes, incubated using linking-antibody for 10 minutes, washed by TBS for $3 \times 5$ minutes, incubated using Streptavidin Biotin for 30 minutes, washed by TBS for $3 \times 5$ minutes and were incubated using chromogen agent diaminobenzidine (DAB) for 5 minutes. After the dye was applied, the preparations were rinsed under running water and were counterstained using Meyer's hematoxyllin for 2 minutes.

On this immunocytochemistry smear result, an assessment was performed using light microscope with a magnification of 400x. The assessment on the expression level of EGFreceptor, c-erbB and HSV-I antigenes is based on the percentage (the number of positive cells towards each oncogene with the number of total cell in each oral cavity mucous smear preparation) 
using the following formula:

Number of positive cells -

Total number of cells (in 1 preparation)

The smear is declared: (1) Positive for EGF-R if there is brownish coloration in the cell's membrane and negative if there is no brownish coloration in the cell's membrane. (2) Positive for c-erbB if there is brownish coloration in the cell's membrane and negative if there is no brownish coloration in the cell's membrane. (3) Positive for HSV-1 if there is brownish coloration in the cell's cytoplasma and negative if there is no brownish coloration in the cell's cytoplasma

\section{RESULT}

Oral cavity mucous swabs were performed to 30 staff of the Faculty of Dentristry Universitas Padjadjaran, who are smokers and 10 non smoker staff. Of this swab, an immunocytochemistry smear was performed using EGF-receptor, c-erbB and HSV-1 antigenes.

From the calculation using one way Anava, it is revealed that increased expressions towards EGFreceptor oncogenes there is significant difference between the smoker group (mild, moderate and severe) and the non smoker group $(p<0.01)$. There is also a very significant difference $(p<0.01)$ between the mild smoker group and the moderate and severe smoker group. Nevertheless, there is no significant difference between moderate smoker group and heavy smoker group ( $p>0.05)$.

From the calculation result using one way Anava, it is revealed that the increased expression towards c-erbB oncogene between the smoker group and non smoker group show a significant difference $(p<0.01)$. There is also a very significant difference $(p<0.01)$ between the mild smoker group and the moderate and severe smoker group. Nevertheless, there is no significant difference between moderate smoker group and heavy smoker group ( $p>0.05$ ).

From the calculation result using one way Anava, it is revealed that the increased expression towards HSV-1 antigene between the smoker group and non smoker group does not show a significant difference $(p>0.05)$.
Table 1. Results of expression level towards EGF-receptor oncogene assessment.

\begin{tabular}{ccccc}
\hline No. & $\begin{array}{c}\text { No } \\
\text { smoker }\end{array}$ & Mild & Moderate & Severe \\
\hline 1 & 0 & 1.152 & 2.795 & 3.007 \\
2 & 0 & 1.659 & 4.145 & 3.912 \\
3 & 0 & 1.915 & 4.230 & 4.400 \\
4 & 0 & 1.965, & 4.500 & 5.694 \\
5 & 0 & 2.385 & 5.414 & 5.859 \\
6 & 0.186 & 2.840 & 6.157 & 6.900 \\
7 & 0.208 & 2.901 & 8.329 & 8.786 \\
8 & 0.479 & 4.876 & 8.786 & 9.197 \\
9 & 0.605 & 5.014 & 10.365 & 10.401 \\
10 & 0.852 & 5.708 & 11.060 & 11.657 \\
\hline $\mathrm{X}$ & 0.2330 & 3.0415 & 6.5781 & 7.0013 \\
\hline
\end{tabular}

Table 2. Results from expression level towards c-erbB oncogene assessment.

\begin{tabular}{ccccc}
\hline No. & $\begin{array}{c}\text { No } \\
\text { smoker }\end{array}$ & Mild & Moderate & Severe \\
\hline 1 & 0 & 0.510 & 3.500 & 3.760 \\
2 & 0 & 0.610 & 4.230 & 5.860 \\
3 & 0 & 1.400 & 4.840 & 5.980 \\
4 & 0 & 1.670 & 5.390 & 6.300 \\
5 & 0 & 1.800 & 5.880 & 7.245 \\
6 & 0 & 2.230 & 6.003 & 8.880 \\
7 & 0.120 & 2.500 & 6.400 & 9.800 \\
8 & 0.198 & 3.500 & 7.859 & 11.230 \\
9 & 0.370 & 3.840 & 11.540 & 11.600 \\
10 & 0.453 & 5.880 & 11.570 & 12.100 \\
\hline $\mathrm{X}$ & 0.2330 & 2.3940 & 6.7212 & 8.2755 \\
\hline
\end{tabular}

Table 2. Results from expression level towards HSV-1 antigene assessment.

\begin{tabular}{ccccc}
\hline No. & $\begin{array}{c}\text { No } \\
\text { smoker }\end{array}$ & Mild & Moderate & Severe \\
\hline 1 & 0 & 0 & 0 & 0 \\
2 & 0 & 0 & 0 & 0 \\
3 & 0 & 0 & 0 & 0 \\
4 & 0 & 0 & 0 & 0 \\
5 & 0 & 0 & 0.224 & 0 \\
6 & 0 & 0.217 & 0.388 & 0 \\
7 & 0.612 & 0.368 & 0.482 & 1.009 \\
8 & 1.023 & 1.021 & 1.035 & 1.010 \\
9 & 1.876 & 2.014 & 1.088 & 1.213 \\
10 & 1.985 & 2.347 & 2.420 & 2.382 \\
\hline $\mathrm{X}$ & 0.5496 & 0.5967 & 0.5637 & 0.5614 \\
\hline
\end{tabular}




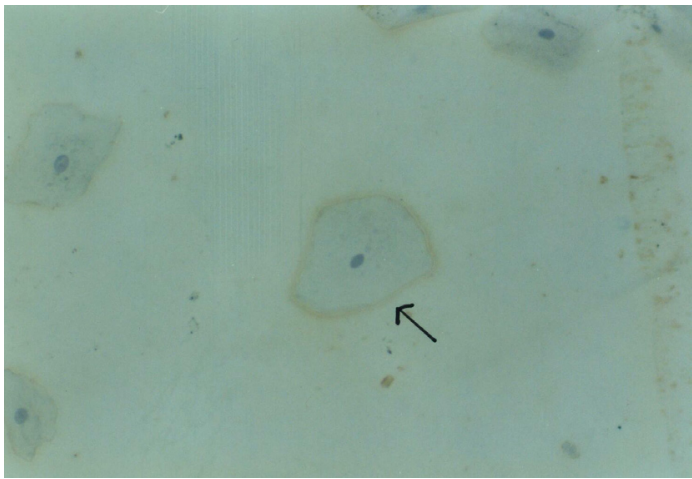

Figure 1. Cells that are positive for EGF-receptor oncogene (200x).

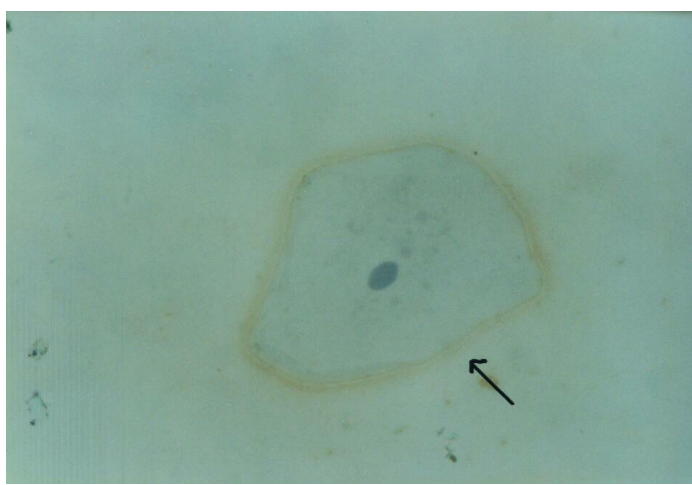

Figure 2. Cells that are positive for EGF-receptor oncogene (400x).

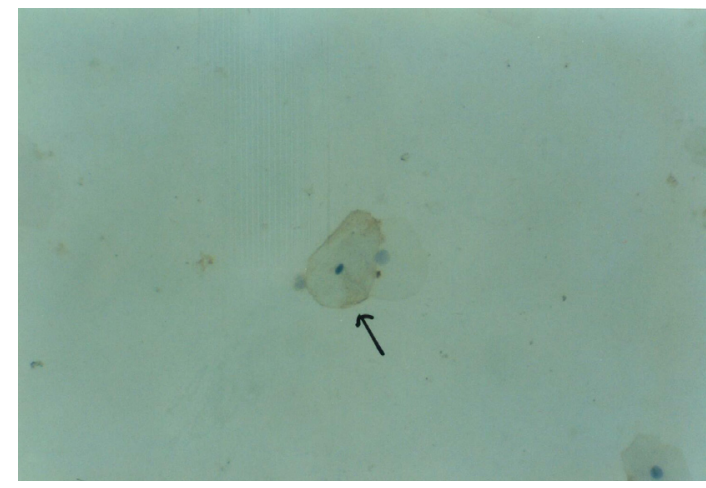

Figure 3. Cells that are positive for c-erbB oncogene (200x).

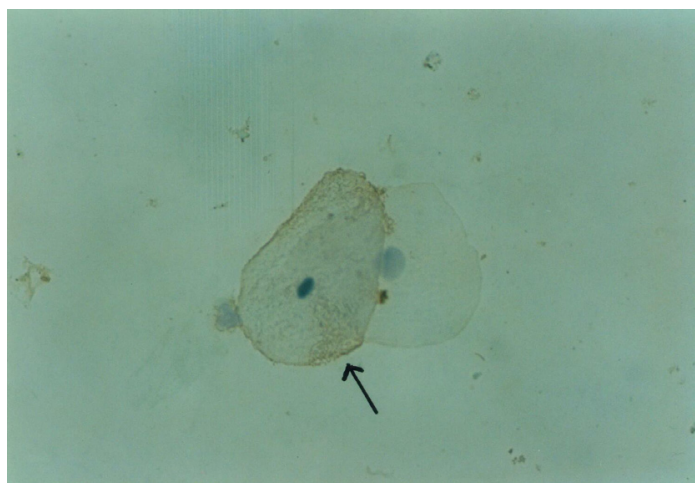

Figure 4. Cells that are positive for c-erbB oncogene (400x).

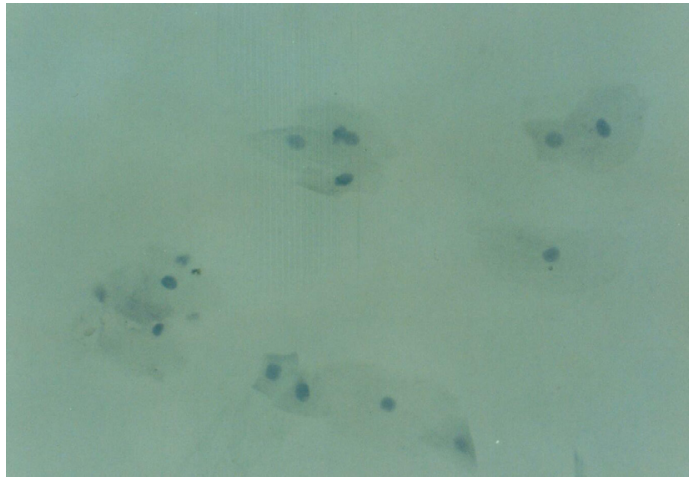

Figure 5. Cells that are negative for EGF-R, c-erbB oncogenes and HSV-1 antigene (200x).

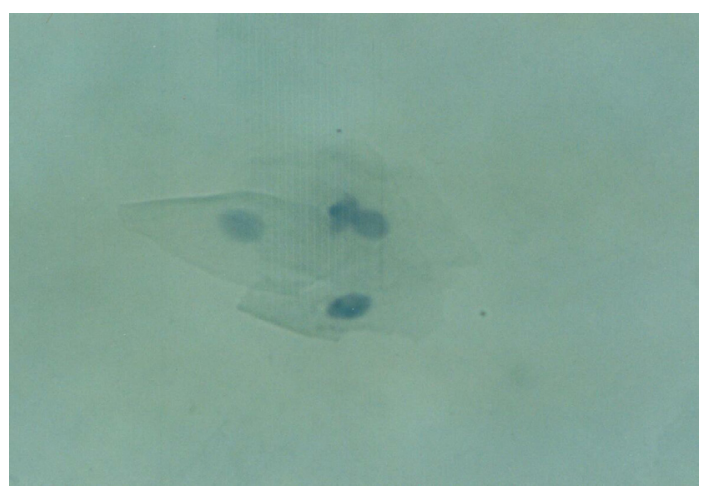

Figure 6. Cells that are negative for EGF-R, c-erbB oncogenes and HSV-1 antigene (400x).

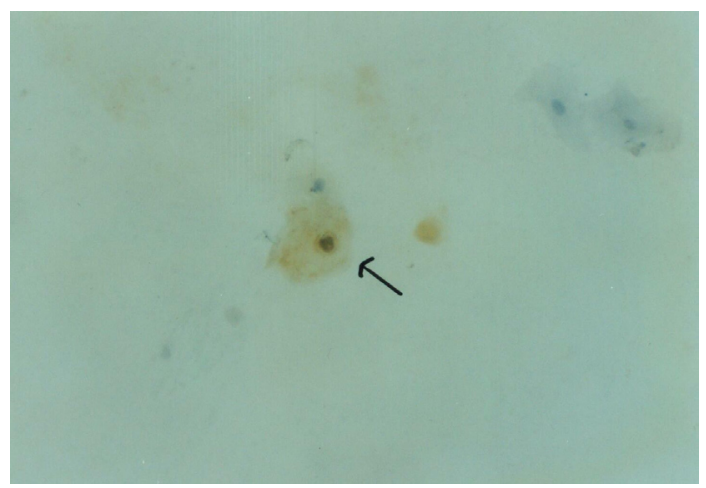

Figure 7. Cells that are positive for HSV-1 antigene (200x).

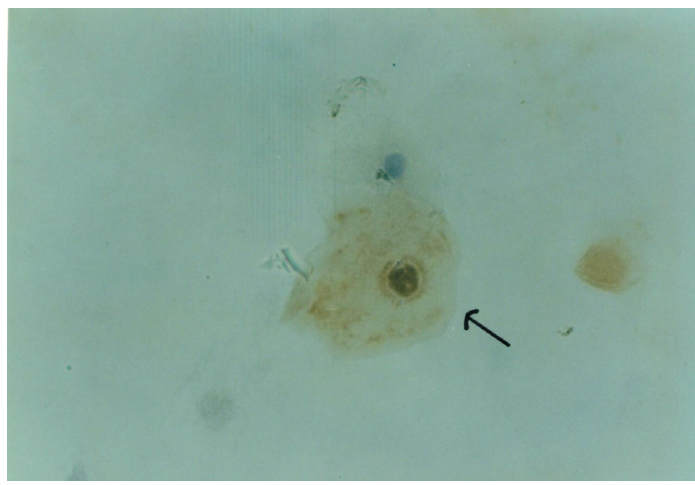

Figure 8. Cells that are positive for HSV-1 antigene (400x). 


\section{DISCUSSION}

Malignant tumors can occur in all human body parts, including the oral cavity. Reports from various pathology center in Indonesia shows that around $3.2 \%$ of the malignant tumors are oral cavity malignant tumors. ${ }^{1}$ Oral cavity malignant tumors, just as other body part malignant tumors, are triggered by intrinsic or extrinsic risk factors. Epidemiologically, it has been shown that smoking is the biggest risk factor for oral cavity malignant tumor. ${ }^{2,3}$

The result of a study done by Schwantz ${ }^{12}$ shows that there is a significant relationship between smoking and malignancy in various part of oral cavity. ${ }^{12} \mathrm{~A}$ research in United States reveals that the risk for oral cavity malignant tumor for smokers is 5 times higher than the non smokers. The smoking habit has been proven to increase the risk of oral cavity malignancy such as stated by Wynder et al. who show that around $97 \%$ of oral cavity malignant tumor patients are smokers. The risk of oral cavity malignant tumor will be bigger for those who are 40 years old or more and heavy smokers. $^{3}$

When the cigarette end is lighted in a high temperature, the cigarette that contains air, steam, gas, liquids, imperfectly burned particles is a very complex organic and inorganic compound mixture. The hot smoke that is inhaled continuously into the mouth is a physical thermal stimulant that brings bad effects on the oral tissue. On the other hand, the cigarette burned contains around 4,000 chemicals including some carcinogenic chemicals, i.e. substances that trigger tumor development, such as tar, nicotine and nitrosamine. The burned cigarette also containes co-carcinogen, i.e. substances that enhance tumor development but do not start it; ciliotoxic agent, i.e. substances that disturb or destroy protective activities of the cilia in the respiratory tract, such as acrolein and hydrogen cyanide and nitrogen oxide..$^{13}$ It is also stated that nitrosamine may create malignancy in human. ${ }^{4}$

Another factor that plays the role for oral cavity malignancy is virus. ${ }^{5}$ Herpes simplex virus in certain environment can be oncogenic and causes cell transformation. ${ }^{6}$ Several reports show that herpes simplex virus with nitrosamine found in tobacco can cause oncogene transformation. ${ }^{7}$
In this research, an immunochemistry examination is performed to assess the expression level of EGF-R, c-erbB and HSV-1 oncogenes in oral mucous smear cells related to various levels of kretek smokers. The immunocytochemistry examination results show that there is a relationship between the expression level of EGF-R and c-erbB oncogene with various levels of kretek smokers. However, there is no relationship between the expression level of HSV-1 antigene expression with various levels of kretek smoker level.

EGF-receptor (EGF-R) is a $170 \mathrm{kD}$ transmembrane tyrosine-spesific phosphokinase found in chromosome-7. In a normal condition, EGF-R can be found in basal cell layer. However, in oral cavity malignancy, they can be found in all layers. ${ }^{6}$ In malignant tumor cells, EGF-receptor will be shown in the cell membrane surface and can be used as an important marker in making an early diagnosis for oral cavity malignant tumor. ${ }^{8}$ In this research result, there will be increased EGF. $\mathrm{R}$ expression level in mild, moderate and severe smoker groups compared to the non smoker group (Tab.1). This shows that the more someone smokes, the higher the number of EGF-r oncogene because there is a bigger possibility of oral cavity malignancy.

c-erbB is a homologous proto-oncogen with EGF-R that codes $185 \mathrm{kD}$ and produces putative growth factor glicoprotein transmembrane of the tyrosinekinase family. Proto-oncogen c-erbB, when it is mutated, will change into an oncogene whose product will be overexpressed. Several studies stated that the inhibiton of apoptosis by the mutation and overexpression of c-erbB oncogene have a big contribution to the tumor growth because the cell survival and proliferation will increase. ${ }^{14}$ The apoptosis inhibition is mostly thought as a result of the missing physiological apoptotic signal/cell death needed. From the result of this research, it seems that there is an increased c-erbB expression level in mild, moderate and severe smokers compared to the non smoker group (Tab. 2). This shows that the more someone smokes, the higher the c-erbB oncogene level due to the apoptosis inhibition and, as a result, there will be higher chance that an oral cavity malignancy will occur.

It has been reported that the antibody for HSV-1 has increased in oral cavity malignant 
tumor patients ${ }^{9,10}$ and the oral cavity malignant tumor cells also contain HSV-1 antigene on the cell membrane surface. ${ }^{11} \mathrm{HSV}-1$ in certain environment can cause the cell to transformed and being and oncogene. ${ }^{7}$ Some reports show that HSV-1 can work synergically with chemical carcinogenes and causes oncogene transformation. ${ }^{7} \mathrm{HSV}-1$ may be a cocarcinogen with tobacco. From this research, there is no increased expression of HSV-1 antigenes in oral cavity mucosal swab cells in the smoker groups, including the mild, moderate and severe smokers, compared to non smoker group (Tab. 3). This is different from the results of other studies that may be due to the small sample size and the small number of Indonesians who are infected by HSV-1 compared to the western. However, the results from a study performed by Shillitoe et al. ${ }^{15}$ also show that not all studies show the existence of HSV in malignancy.

In this research, there is also no clear relationship between the involvement of herpes simplex virus and the occurrence of oral cavity malignancy. This implies that despite the unclear involvement of the virus, the oncogene transformation from nitrosamine still happens. So, smoking makes a malignancy more probable compared to virus involvement.

From all results in this study it is apparent that there is EGF-R and c-erbB oncogenes activation in smoker oral cavity mucous swab preparation. According to several studies, it is revealed that the oncogen activation is related to a genetic change that is responsible for malignant change in the future, including oral cavity malignancy. ${ }^{16}$ From this research it is concluded that moderate and severe smoking habit may cause genetic changes or mutation that may create changes towards oral cavity malignancy.

\section{CONCLUSION}

The more cigarettes consumed by a smoker, the bigger the possibility for oral cavity malignancy. No clear relationship between smoking with Herpes Simplex virus involvement and the occurence of oral cavity malignancy. Smoking is an important possibility for oral cavity malignancy. Antibody towards EGF-R and cerb-B oncogene can become a marker for early detection of the possibility of oral cavity malignancy caused by smoking.

\section{REFERENCES}

1. Badan Registrasi Kanker, Ikatan Ahli Patologi Indonesia \& Yayasan Kanker Indonesia.Kanker di Indonesia tahun 1998, data histopatologi. Jakarta: Direktorat Jendral Pelayanan Medik Departemen Kesehatan RI; 1998.

2. Day GL, Blot WJ, Shore RE. Second cancers following oral and pharyngeal cancers; role of tobacco and alcohol. J Natl Cancer Inst 1994;86(2):131-7.

3. Genco RJ, Goldman HM, Cohen DW. Contemporary periodontics. St. Louis: The C.V. Mosby Co.; 1990. p. 278-83.

4. Preston MS. Evaluation of the evidence that tobacco-specific nitrosamines (TSNA) cause cancer in humans. Crit Rev Toxicol 1991;21(4):295-6.

5. Steele C, Shillitoe EJ. Viruses and oral cancer. Crit Rev Oral Biol Med 1991;2(2):153-75.

6. Scully $C$. Viruses and oral squamous carcinoma. Oral Oncol Europ J Cancer 1992;28B:57-60.

7. Park NH, Dokko H, Li SL, Cherrick HM. Synergism of Herpes Simplex virus and tobacco-specific $\mathrm{N}$-nitrosamines in cell transformation. J Oral Maxillofac Surg 1991;49:276-81.

8. Fujibayashi T. Immunological consideration on oral malignant and premalignant lesions. Oral Oncologi 1991;1:40-2.

9. Kumari TV, Shanmughan J, Vasudevan DM. Detection of antibodies against Herpes Simplex virus in patients with oral cancer. Ind J Med Res 1982;75:590-2.

10. Kumari TV, Thankamani V, Vasudevan DM. Detection of HSV-1 antigen in patients with oral cancer. Ind J Cancer 1985;21:137-40.

11. Kumari TV, Vasudevan DM, Ankathil R, Remani P, Vijayakumar T. Detection of HSV1 antigen in patients with oral cancer by immunofluorescence and immunoperoxidase techniques. J Exp Pathol 1987;3:75-86.

12. Schwantz in Ruslan G. Efek merokok terhadap rongga mulut. J PDGI 1993. p. 22-5

13. Aditama TY. Rokok dan kesehatan. Jakarta: Universitas Indonesia-Press; 1992.

14. Syawqie A. Kaitan tingkat imunoekspresi ras P21, c-erbB, dan P-53 dengan patogenesis serta derajat keganasan tumor adenoma pleomorfik kelenjar liur parotis. Thesis. Bandung: Universitas Padjadjaran; 1997. p. 63. 
15. Shillitoe EJ, Hwang CBC, Silverman S, Greenspan JS. Examination of oral cancer tissue for the presence of the proteins ICP4, ICP5, ICP6, ICP8 and gB of Herpes Simplex type I. J Natl Cancer Inst 1986;76:371-4.
16. Fied JK. Oncogenes and tumour-supressor genes in squamous cell carcinoma of the head and neck. Oral Oncol Europ J Cancer 1992:28 B:67-76. 